\title{
Biogas Production: The Fundamental Processes
}

\author{
Iftikhar A Raja ${ }^{1, *}$, Shabir Wazir ${ }^{2}$ \\ ${ }^{1}$ Department of Environmental Sciences, COMSATS Institute of Information Technology, Pakistan \\ ${ }^{2}$ Cattlekit, Mohlin Lal, Pakistan
}

Copyright $(2017$ by authors, all rights reserved. Authors agree that this article remains permanently open access under the terms of the Creative Commons Attribution License 4.0 International License

\begin{abstract}
Biogas appears to have potential as an alternative energy source particularly for rural community. The technology is simple and is booming in the world energy markets. Biomass resources are being available worldwide, new high technology with improved efficiency plants have been introduced. While based on ongoing research and development in this field smart biogas plants will be in operation soon. This overview of some salient points and perspectives of biogas technology explains the fundamental processes, basic technology used in production of biogas and available resources. The biogas plants can be used where ever the bio-waste is available/ dumped. The study suggests that biogas technology must be encouraged, promoted, and invested in for implementation and demonstration, especially in remote rural areas.
\end{abstract}

Keywords Anaerobic Digestion, Bioenergy, Biomass, Biogas, Climate Changes, Waste Management

\section{Introduction}

For sustainable development a basic requirement is the availability of adequate resources, particularly energy services, to satisfy the basic needs of an individual and the society for improving the social welfare and economic development [1]. Energy as an input for goods and services is a prerequisite for economic development. Comparative studies show a strong positive correlation between per capita income and energy consumption [2]. Hence to ensure the economic development and increase in per capita incomes the energy demand patterns will also change, and the rural energy planning process must be programmed to adapt to these changes. Energy is obtained from both renewable and non-renewable sources. Non-renewable sources are mainly fossil fuels (oil, gas and coal), contributing 81.2\% to world energy consumption. In Pakistan the fossil fuel contribution is $60.1 \%$ [2, 3]. Major proportion of the fossil is used to maintain the commercial energy supply i.e. electricity generation. For the electricity network stability, the load balance heavily relies on fossil fuel power plants. Fossil fuels contribute around 70\% of global electricity generation [4].

Majority of the inhabitants of developing countries live in rural areas. They depend heavily on solid fuels to meet their basic energy requirements, where the traditional biomass is the dominant contributor. The reliance on these traditional fuels comes at great environmental, social and human costs [5]. Deforestation rates in developing countries like Cambodia are among the highest of the region and fuel wood is one of the factors contributing to that. The harmful environmental, health and social effects associated with the use of traditional biomass and fossil fuel has enhanced the growing interest in the search for alternate cleaner source of energy globally [6]. Efforts to reduce the enormous environmental impacts and associated human health and socioeconomic implications by shifting to efficient and cleaner biomass-derived fuels (biogas) have had some success, but much more needs to be done. Biogas can positively contribute to climate goals and rural livelihoods.

Fossil fuel reserves are limited in nature and are likely to finish sooner or later. The growth in population, ongoing developments around the world and human efforts for better life make it unlikely that today's consumption will not increase in the future. So we need to think, what should we do about it? After the oil crisis of 1970's, the world has diverted its attention and looking for replacement of fossil fuels with alternative/renewable energy sources [7]. It is believed now that after 2050's, 50\% of world energy share will come from renewable energy resources. The conventional use of fossil fuels is also stressing on environment, contributing to greenhouse effects, global warming and atmospheric pollution. There is also pressing need to find alternate and ecologically sound energy sources for the future. Most emerging alternative sources of energy include solar energy, nuclear energy and bio-energy (biomass). Among these, bio-energy is more promising, cost effective and ever available. There are three major ways in which the energy from biomass is utilized: direct burning, conversion to gas, and conversion to biofuel (ethanol and biodiesel).

The energy of the future must be regenerative and sustainable and bio-energy (biogas) - biological conversion of organic materials/waste by anaerobic digestion using 
engineered reactors has the potential. Anaerobic digestion is a technology widely used for treatment of organic waste for biogas production $[8,9]$. Apart from an important source of energy, particularly for the rural community [10], it contributes to climate change mitigation by saving greenhouse gas emissions from decay of organic materials and promotes the preservation of the traditional extensive uses of the ecosystems [11].

In the backdrop of pressing needs of energy, this article throw light on production and consumption of biogas, at small scale (domestic level) and the study provides a foundation to gain information about biogas production and further development.

\section{Biogas Energy}

Biogas originates from biogenic material and is a type of biofuels, typically referred to a gas produced by bacteria fermentation of organic material under anaerobic condition (in the absence of oxygen). It can be produced from a wide variety of available organic materials and wastes, including sewage sludge, animal manure, and municipal organic waste. The materials like biodegradable waste, straw, manure, sugarcane and byproducts from agricultural and industrial processes and specially grown energy crops can also be used for the production of energy.

Anaerobic digestion is a simple technology widely used for processing the biodegradable, organic waste for the biogas production. Animal manure (cow dung) is used as inoculum, pretreatment of substrate. The thermophilic conditions improved the biogas yield by approximately $92 \%$. The fermentation of organic waste involves biological and chemical and the process is equally beneficial in waste management. During the process, large organic polymers that make up biomass are broken down into smaller molecules by chemicals and microorganisms. Upon completion of the anaerobic digestion process, the biomass is converted into biogas, (methane, carbon dioxide and traces of other contaminant gases), as well as liquid digestate (nutrient rich fertilizer).

\subsection{Biochemical Process}

Anaerobic digestion is a complex process that takes place in four biological and chemical stages [12] i.e. hydrolysis, acidogenesis, acetogenesis and methanogenesis. These stages are illustrated in Figure 1. The individual degradation steps are carried out by different consortia of microorganisms, which partly stand in syntrophic interrelation and place different requirements on the environment [13]. Hydrolyzing and fermenting microorganisms are responsible for the initial attack on polymers and monomers and produce mainly acetate, hydrogen and varying amounts of volatile fatty acids such as propionate and butyrate. Hydrolytic microorganisms excrete hydrolytic enzymes, e.g., cellulase, cellobiase, xylanase, amylase, lipase, and protease. A complex consortium of microorganisms participates in the hydrolysis and fermentation of organic material. Most of the bacteria are strict anaerobes such as Bacteriocides, Clostridia, and Bifidobacteria. Furthermore, some facultative anaerobes such as Enterobacteriaceae, and Streptococci take part. The higher volatile fatty acids are converted into acetate and hydrogen by obligate hydrogen producing acetogenic bacteria. The accumulation of hydrogen can inhibit the metabolism of the acetogenic bacteria. The maintenance of an extremely low partial pressure of hydrogen is essential for the acetogenic and $\mathrm{H}_{2}$-producing bacteria. Although many microbial details of metabolic networks in a methanogenic consortium are not clear, present knowledge suggests that hydrogen may be a limiting substrate for methanogens [14]. At the end of the degradation chain, two groups of methanogenic bacteria produce methane from acetate or hydrogen and carbon dioxide.

The four stages of anaerobic fermentation to accomplish the methane-production process are discussed below.

$\underline{\text { Matter }} \rightarrow \underline{\text { Hydrobsis }} \rightarrow \underline{\text { Acidogenesis }} \rightarrow \underline{\text { Acetogenesis }} \rightarrow \underline{\text { Methanogenesis }}$

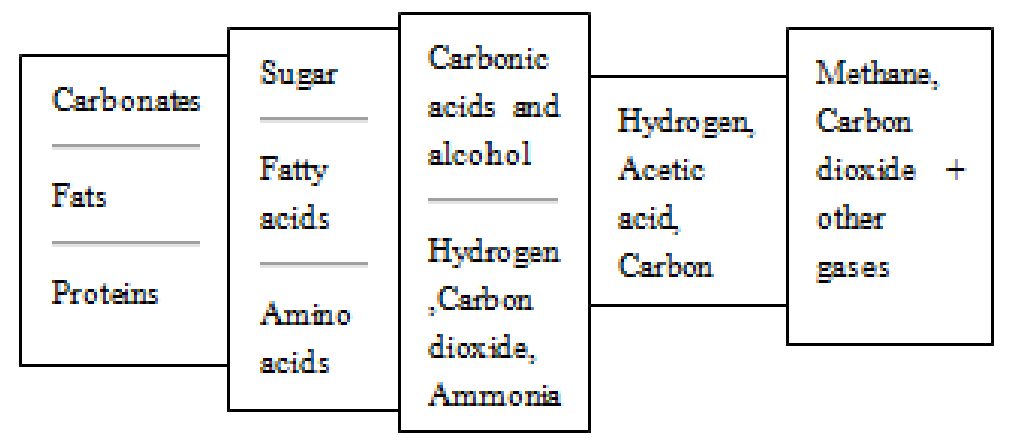

Figure 1. Biochemical stages during fermentation process 


\section{[1] Hydrolysis}

Biomass is normally comprised of large organic polymers proteins, fats and carbohydrates. These are broken down into smaller molecules such as amino acids, fatty acids, and simple sugars. It is the essential first step in anaerobic fermentation; fermentative bacteria hydrolyze the complex organic matter into soluble molecules. Some of the products of hydrolysis, including hydrogen and acetate may be used by methanogens later in the anaerobic digestion process. Majority of the molecules, which are still relatively large, must be further broken down in the process of acidogenesis so that they may be used to create methane.

\section{[2] Acidogenesis}

Acidogenesis is the next step of anaerobic digestion where acidogenic microorganisms further break down the biomass and organic products after hydrolysis. These fermentative bacteria produce an acidic environment in the digestive tank while creating ammonia, $\mathrm{H}_{2}, \mathrm{CO}_{2}, \mathrm{H}_{2} \mathrm{~S}$, shorter volatile fatty acids and organic acids, as well as trace amounts of other byproducts. The principal acids produced are acetic acid, propionic acid, butyric acid etc.

\section{[3] Acetogenesis}

In general, acetogenesis is the creation of acetate, a derivative of acetic acid, from carbon and energy sources by acetogens. These microorganisms catabolize many of the products created in acidogenesis into acetic acid, $\mathrm{CO}_{2}$ and $\mathrm{H}_{2}$. Acetogens break down the biomass to a point to which methanogens can utilize much of the remaining material to create methane.

\section{[4] Methanogenesis}

Methanogenesis constitutes the final stage of anaerobic digestion in which methanogens create methane from the final products of acetogenesis as well as from some of the intermediate products from hydrolysis and acidogenesis. There are two general pathways involving the use of acetic acid and carbon dioxide, the two main products of the first three steps of anaerobic digestion, to create methane in methanogenesis:

$$
\begin{gathered}
\mathrm{CO}_{2}+4 \mathrm{H}_{2} \rightarrow \mathrm{CH}_{4}+2 \mathrm{H}_{2} \mathrm{O} \\
\mathrm{CH}_{3} \mathrm{COOH} \rightarrow \mathrm{CH}_{4}+\mathrm{CO}_{2}
\end{gathered}
$$

While $\mathrm{CO}_{2}$ can be converted into methane and water through the reaction, the main mechanism to create methane in methanogenesis is the path involving acetic acid. This stage leads to generation of methane and $\mathrm{CO}_{2}$, the two main products of anaerobic digestion.

\subsection{Principle of Gas Production.}

With the decomposition of organic or biological materials various gases are released. The organic decomposition can occur in two basic paths: aerobic (in the presence of oxygen), and anaerobic (in the absence of oxygen) decomposition.
However, the products of decomposition are quite different in each case. Aerobic decomposition (fermentation) produces carbon dioxide, ammonia and a few other gases in small quantities, significant amount of heat and a final product that can be used as a fertilizer. Anaerobic decomposition produces methane, carbon dioxide, and traces of other gases, very little heat and a final product with higher nitrogen content than is produced by aerobic fermentation. Anaerobic decomposition is a two-stage process as specific bacteria feed on certain organic materials. In the first stage, acidic bacteria dismantle the complex organic molecules into peptides, glycerol, alcohol and the simpler sugars. When these compounds are produced in sufficient quantities, a second type of bacteria starts to convert these simpler compounds into methane. These methane producing bacteria are particularly influenced by the ambient conditions, which can slow or terminate the process if they do not lie within a fairly narrow band.

Anaerobic digestion is most commonly used to convert organic material into biogas from high moisture content organic wastes like manure (animal and human) and crop residues. The average retention time for animal waste is 20-40 days and for organic waste it is 60-90 days [15]. The resultant biogas contains 55 to $80 \%$ methane - depending upon waste type [16].

\subsection{Composition of Biogas}

Principal gases produced are methane and carbon dioxide. Biogas is about $20 \%$ lighter than air and has an ignition temperature in the range of $50^{\circ} \mathrm{C}$ to $750^{\circ} \mathrm{C}$. It is odorless and colorless gas that burns with clear blue flame similar to that of LPG gas. The calorific value of $1 \mathrm{~m}^{3}$ is about $22 \mathrm{MJ}$ if burns with $60 \%$ efficiency. The composition of gas varies with raw material used. However, typical composition is given in Table -1[17, 18].

Table 1. Typical composition of biogas

\begin{tabular}{|c|c|}
\hline Matter & Percentage \\
\hline Methane, $\mathrm{CH}_{4}$ & $50-75$ \\
\hline Carbon dioxide, $\mathrm{CO}_{2}$ & $25-50$ \\
\hline Nitrogen, $\mathrm{N}_{2}$ & $0-10$ \\
\hline Hydrogen, $\mathrm{H}_{2}$ & $0-1$ \\
\hline Hydrogen sulfide, $\mathrm{H}_{2} \mathrm{~S}$ & Traces \\
\hline Water vapour & Traces \\
\hline Oxygen, $\mathrm{O}_{2}$ & $0-2$ \\
\hline
\end{tabular}

\subsection{Types of Biogas Reactors}

There are number designs but two types of biogas reactors are popular: floating-drum plants and fixed-dome plants. The main design elements of small-scale biogas reactors common to both types are: a digesting chamber (airtight vessel) provided with an inlet and outlet, an airtight biogas collection (e.g. upper part of the reactor) and an expansions 
chamber. Optionally, there are connections from the toilet and a grinder/mixture for the kitchen and garden wastes.

\subsubsection{Fixed-dome Reactors}

A fixed-dome plant consists of a fixed digester combined with non-movable gas holder, placed on top of the digester or gas collected in the space in upper part of digester. When gas production starts, the slurry is displaced into the compensation tank. Gas pressure increases with the volume of gas generated and the height difference between the slurry level in the digester and the slurry level in the compensation tank.

The cost of a fixed-dome biogas plants is relatively low. The plant is simple as there are no moving parts and also no rusting steel parts and hence a long life of the plant (20 years or more) can be expected. The digesting tank is constructed underground that protects it from physical damage and saving space. While the underground digester is protected from low temperatures at night and during cold seasons, sunshine and warm seasons take longer to heat up the digester. No day/night fluctuations of temperature in the digester positively influence the bacteriological processes. The construction of fixed dome plants is labor-intensive, thus creating local employment. Fixed-dome plants are not easy to build. They should only be built where construction can be supervised by experienced biogas technicians. Otherwise plants may not be gas-tight (porosity and cracks).

\subsubsection{Floating-drum Reactors}

Floating-drum plants consist of an underground digester (cylindrical or dome-shaped) and a moving gasholder. The gas-holder floats over the fermentation slurry. The gas is collected in the drum, which moves up and down, according to the amount of gas stored. The gas drum is prevented from tilting by a guiding frame. The position the drum indicates the amount/pressure of gas available.

The construction is relatively easy, however, the cost of the steel drum is high and furthermore the steel parts are susceptible to corrosion. The floating drum plants thus have a shorter life span than fixed-dome plants. Also regular maintenance costs for the painting of the drum arise.

After the introduction of cheaper fixed-dome Chinese model, the floating drum plants are becoming obsolete. Apart from high investment and maintenance cost of floating drum plants have some design weakness, too.

\subsection{Biogas Plant Installation}

Although a number biogas plants have been used but in practice two popular simple designs - "Floating Drum" and "Dome shaped" are developed for use in developing countries. Both operate in the same way but they differ in design of digestion chamber.

a Iron made Floating Drum Plant. The gas produced is accumulated in a big heavy weight movable iron drum, from where it is further piped out. It is short lived owing to iron rusting phenomenon. b Concrete made Dome shaped Plant. The gas produced is accumulated in a dome made up of good quality concrete. Its life depends upon quality of concrete. It is preferable over iron made cylinder, it reduces heat factor and is cost effective.

\subsubsection{Basic Design}

A typical biogas plant, as shown in the diagram in Figure 2, should comprise of following parts:

a Digesting Chamber (A) - a deep airtight circular pit, the digestion chamber is filled with organic solid waste mixed with water, fermentation (anaerobic decomposition) occurs and gas is produced and rises up within the chamber.

b Inlet Pipe B - to be used to pour the raw material into base of digester.

c Outlet Pipe C - meant to take out sullies from digester.

d Mixing Tank (Inlet) D - to be used for preparing homogenous mixture of the raw material, usually an equal amounts of biomass and water to feed into digester.

e Compensation \& Removal Tank (Slurry Outlet) solid (slurries) and liquid waste from digestion chamber "A" are collected through a pipe $\mathrm{C}$ and can be used as fertilizer being rich in nitrogen contents.

f Gas Accumulator (F) - gas produced is collected in an accumulator that may be the floating drum or a concrete made dome over the digestion chamber.

g Gas Collection and Distribution (G) - At the top of accumulator gas collection and distribution system is fixed, which is further channeled to the consumption unit.

\subsubsection{Construction Materials}

A schematic diagram of a small biogas plant for domestic use is given in Figure 3, [19]. The life span of a plant very much depends on the quality of the material used for its construction. Therefore, quality materials should be used, preferably locally available to reduce the cost. A brief description and specifications is given below.

- Cement - High quality branded cement, sealed bags, protected from moisture and contamination.

- $\quad$ Sand - Fine aggregates or sand, clean and free from coagulated lumps, impurities especially mud. Coarse and granular sand can be used for concreting work but fine sand better for plastering.

- Gravel - Stone crushed, hard, strong and clean, it under $2 \mathrm{~cm}$ in size.

- $\quad$ Water - Clean water, $\mathrm{pH}$ value not exceeding 7.

- Bricks - Regular shaped, kiln burnt bricks, soaked before use.

- Stones - In case of stone masonry, clean, strong and good quality stones size $7-30 \mathrm{~cm}$ in diameter.

- Steel - $6 \mathrm{~mm}$ steel rods, $50 \mathrm{~m}$ for $4 \mathrm{~m}^{3}$ plant, $60 \mathrm{~m}$ for $6 \mathrm{~m}^{3}$ and so on.

- $\quad$ Pipes and appliances - as appropriate. 


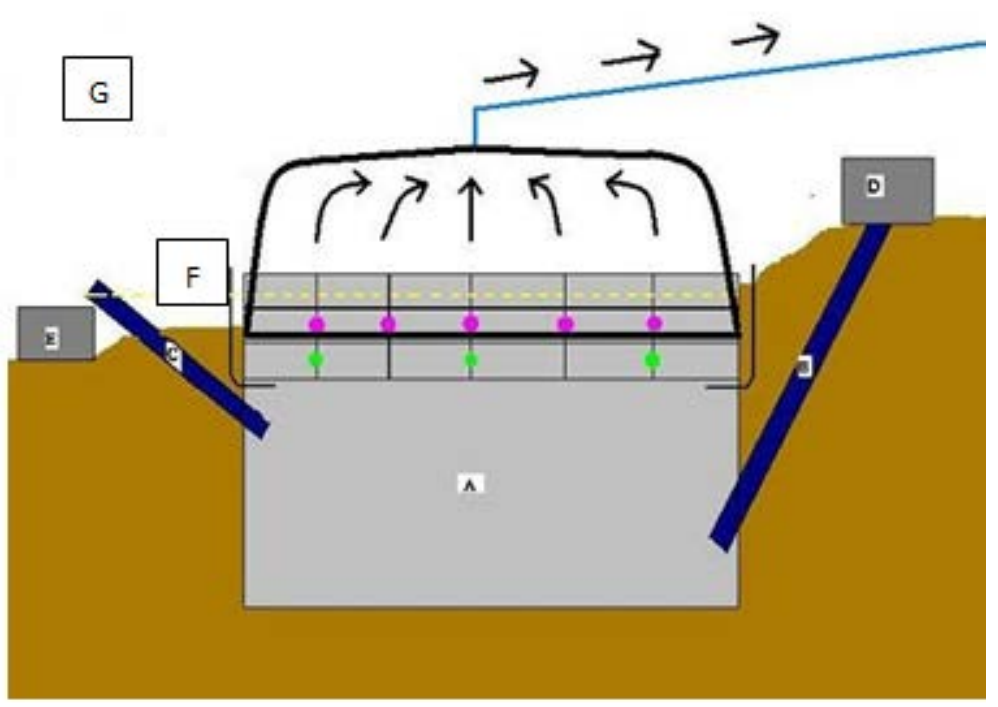

Figure 2. Basic design component of a biogas plant

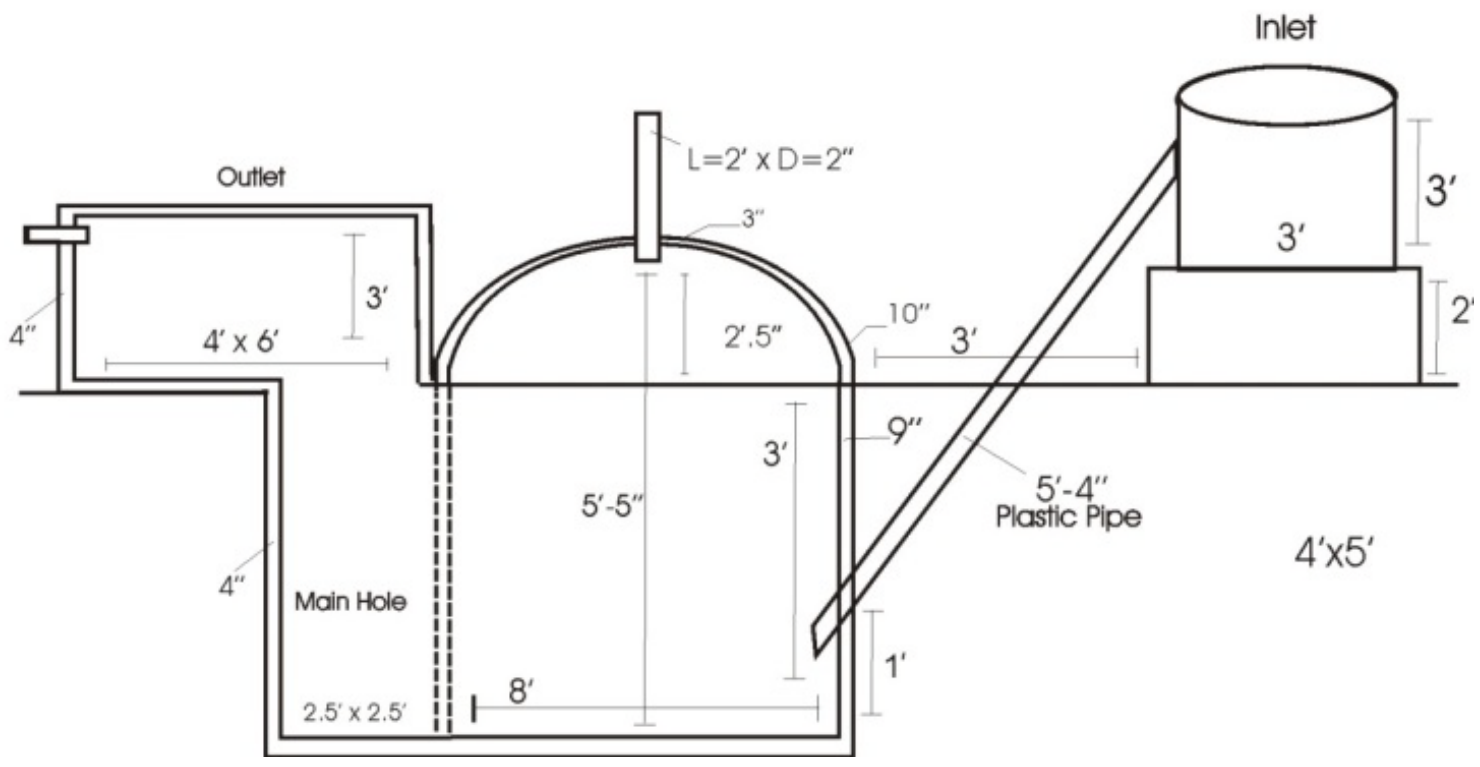

Figure 3. Schematic diagram (dimensions) of small domestic unit

\subsubsection{Biogas Plant Operation}

The steps required for the operation of biogas plant are:

a Feeding - Initially feed the digester at optimum level with mixture of water and raw material at a ratio of 1:1. After 1-2 weeks of operation, continuous daily feeding is recommended.

b Seeding - Common practice involves seeding with an adequate population of both the acid-forming and methanogenic bacteria. Actively digesting sludge from a sewage plant constitutes ideal "seed" material. As a general guideline, the seed material should be twice the volume of the fresh manure slurry during the start-up phase, with a gradual decrease in amount added over a three-week period. If the digester accumulates volatile acids as a result of overloading, the situation can be remedied by reseeding, or by the addition of lime or other alkali.

c Stirring/Agitation - Stirring of digester contents is recommended at regular intervals may be manually in order to avoid formation of scum.

d Gas Collection - Gas can be collected from the drum through a non-return valve system. Preferably a water pipe is most suitable than gas pipe. Gas pipe should be regularly cleaned to remove moisture contents.

\subsection{Factors Affecting Gas Production}

The potential gas volumes produced from bio resources depends on many factors, some the factor are given below.

a Temperature. Although there are no standard rules but for optimum process stability, the temperature should be 
carefully regulated within a narrow range of the operating temperature. With a mesophilic flora, digestion proceeds best at $30-40^{\circ} \mathrm{C}$; with thermophiles, the optimum range is $50-60^{\circ} \mathrm{C}$. The choice of temperature to be used is influenced by climatic considerations. In warm climates digesters may be operated without added heat. As a safety measure, it is common practice either to bury the digesters in the ground on account of the advantageous insulating properties of the soil, or to use a greenhouse covering. In cold climate where heating of digesting material is required, the costs can be minimized through the use of natural materials such as leaves, sawdust, straw, etc., which are composted in batches in a separate compartment around the digester. For ideal fermentation the temperature should be maintained above $30^{\circ} \mathrm{C}$.

b pH. Low pH inhibits the growth of the methanogenic bacteria and gas generation and is often the result of overloading. Efficient digestion occurs at a $\mathrm{pH}$ near neutrality, within a range of 6.0 - 8.0. A slightly alkaline state is an indication that $\mathrm{pH}$ fluctuations are not too drastic. Low $\mathrm{pH}$ may be relieved by dilution or by the addition of lime.

c Nutrients. The maintenance of optimum microbiological activity in the digester is crucial to gas generation and consequently is related to nutrient availability. Two of the most important nutrients are carbon $(\mathrm{C})$ and nitrogen $(\mathrm{N})$ and overall $\mathrm{C} / \mathrm{N}$ ratio is a critical factor for raw material choice. Domestic sewage and animal and poultry wastes are examples of N-rich materials that provide nutrients for the growth and multiplication of the anaerobic organisms. On the other hand, N-poor materials like agriculture waste, green grass, etc., are rich in carbohydrate substances that are essential for gas production. Excess of nitrogen leads to the formation of $\mathrm{NH}_{3}$, the concentration of which inhibits further growth. Ammonia toxicity can be eased by lower loading or dilution. In practice, it is important to maintain, by weight, a $\mathrm{C} / \mathrm{N}$ ratio close to $30: 1$ for achieving an optimum rate of digestion. The $\mathrm{C} / \mathrm{N}$ ratio can carefully be manipulated by combining materials low in carbon with those that are high in nitrogen, and vice versa.

d Toxic Materials. Wastes and biodegradable residues are often accompanied by a variety of pollutants that could inhibit anaerobic digestion. Potential toxicity due to ammonia can be corrected by remedying the $\mathrm{C} / \mathrm{N}$ ratio of manure through the addition of shredded bagasse or straw, or by dilution. Common toxic substances are the soluble salts of copper, zinc, nickel, mercury, and chromium. On the other hand, salts of sodium, potassium, calcium, and magnesium may be stimulatory or toxic in action, both manifestations being associated with the cation rather than the anionic portion of the salt. Pesticides and synthetic detergents may also be troublesome to the process.

\subsection{Resources of Biomass}

Biomass energy resources are mainly used through conventional technologies, by rural community to meet their basic energy needs, cooking and heating. Meanwhile biomass gasification (biogas) and bio-liquefaction (biodiesel and bioethanol) technologies are gradually being developed [20]. Among these biogas production technology is simple to install and operate. The technology is cost effective and is well taken around the world.

Although almost all biodegradable materials can be used for the production of biogas but there are four major sources of biomass worth to be considered: agricultural and forestry residues, municipal solid waste including kitchen waste, industrial waste, and specifically grown bioenergy crops.

- Agricultural and forest residues - Wood and woody debris left after logging, agriculture waste, crop residues and energy crops, algal biomass, etc.

- Community based waste - Municipal solid waste (MSW) much of which is organic including cooked and uncooked kitchen, sewage sludge, grass clippings and garden waste.

- Industrial waste - Large quantity solid and processed liquors is generated by the industries like breweries, sugar mills, distilleries, food-processing industries, tanneries, paper and pulp industries, wood works and furniture.

- Animal manure and Human Excreta - Animal dung and human excreta, poultry waste.

- Marine feedstock - Seaweeds, fish and shellfish.

\subsection{Digestion and Feeding}

The complete anaerobic digestion takes about 16 weeks at warm temperatures. Gas production can be accelerated and made more consistent by continuously feeding the digester with small amounts of waste daily. This will also preserve the nitrogen level in the slurry for use as fertilizer. The advantage of continuous-feed plants is that the bacteria receive a regular supply of substrate and are therefore able to generate a more constant supply of biogas.

Table 2. Methane contents of some typical biomass material.

\begin{tabular}{|c|c|}
\hline Materials & Methane Contents \\
\hline Cattle manure & $65 \%$ \\
\hline Poultry manure & $60 \%$ \\
\hline Farmyard manure & $55 \%$ \\
\hline Straw & $59 \%$ \\
\hline Grass & $70 \%$ \\
\hline Leaves & $58 \%$ \\
\hline Kitchen waste & $50 \%$ \\
\hline Algae & $63 \%$ \\
\hline Water hyacinths & $52 \%$ \\
\hline
\end{tabular}


The potential of gas volume produced depends on the feed material. Some typical values of methane content of various feed materials are given in Table 2 and some basic parameters regarding feeding and domestic biogas use are given in Table 3 . The methane generation depends on the digestion temperature. Low digestion temperatures give high methane content, but less gas is then produced.

Table 3. Some basic parameters regarding biogas production and use

\begin{tabular}{|c|c|}
\hline Parameters & Details \\
\hline $\begin{array}{c}\text { Digesting } \\
\text { temperature }\end{array}$ & 20 to $35^{\circ} \mathrm{C}$ \\
\hline Retention time & $\begin{array}{c}\text { Depending on material, } \\
3-40 \text { to days }\end{array}$ \\
\hline $\begin{array}{c}\text { Biogas energy } \\
\text { contents }\end{array}$ & $6 \mathrm{kWh} / \mathrm{m}^{3}=0.61 \mathrm{~L}$ diesel fuel \\
\hline Biogas generation & $\begin{array}{c}0.3-0.5 \mathrm{~m}^{3} \text { gas } / \mathrm{m}^{3} \\
\text { digester volume } / \text { day }\end{array}$ \\
\hline Human yields & $0.02 \mathrm{~m}^{3} /$ person per day \\
\hline Cow yields & $\begin{array}{c}0.4 \mathrm{~m}^{3} / \mathrm{Kg} \text { dung, } \\
\text { retention time } 40 \text { days }\end{array}$ \\
\hline $\begin{array}{c}80 \text { liter } / \mathrm{Kg}, \\
\text { retention time } 3-4 \text { days }\end{array}$ \\
\hline $\begin{array}{c}500 \text { liter } / \mathrm{Kg}, \\
\text { Food wastention time } 5 \text { days }\end{array}$ \\
\hline Food grain \\
\hline $\begin{array}{c}\text { Gas requirement } \\
\text { (cooking) }\end{array}$ & 0.3 to $0.9 \mathrm{~m}^{3} / \mathrm{person}$ per day \\
\hline $\begin{array}{c}\text { Gas requirement } \\
\text { (lighting) }\end{array}$ & 0.1 to $0.15 \mathrm{~m}^{3} / \mathrm{h}$ - one lamp \\
\hline
\end{tabular}

\subsection{Status and Prospective of Biogas Development}

The potential for and benefits of small scale biogas plant have been reviewed and are found considerable, particularly in the rural areas of developing countries [21, 22]. Whereas majority of the inhabitants, over $80 \%$ live in rural areas. They heavily rely on solid fuels to meet their basic energy requirements, mostly for cooking and heating, where the traditional biomass is the dominant contributor. It contributes to primary energy supply in Ghana about $72 \%$ [23], 27\% Pakistan [24]. Cambodia has the highest percentage (91\%) of the population relying on fuel wood, and the highest per capita consumption of fuel wood, in the Asia-Pacific region $[25,26]$

Agriculture is primary source of income and livelihood of the rural population. The dominant farming system is an integrated livestock, crop cultivation system, relies on biomass and animal manure [27]. Usually the livestock sector is dominated by smallholders, a few animals and chickens and most of households have enough animals to run a small scale biogass plant to produce biogas and organic fertilizers. For Cambodia around 500,000 rural households could install a biodigester [28]. Ghana has technical potential of constructing about 278,000 biogas plants [23]. An assessment on the potential of and need for, domestic biogas in Africa has been carried out by Felixter Heegde and Kai Sonder [29]. The technical potential based on the number of households that can meet the two basic requirements - sufficient availability of dung and water to run a biogas installation, are enormous. Although biogas can be generated from a score of organic materials, in Africa cattle dung from husbandry is best suited to feeding a domestic installation. [29]

In order to contain the uncertainty usually associated with transformation of the economy, the biogas, a renewable energy source has been well taken around world equally by developing and developed countries, and also oil exporting countries. Target-oriented and subsidy-driven national programmes have been initiated: Indian technology centric National Programme on Biogas Development, energizing all households. [30], Cambodian National Biodigester Programme (NBP) for implementation at small scale farmer level - very much based the Nepalese national Biogas Program [28]. Biogas Initiative supported with government subsidies inspired implementation on initial phase in Rwanda at [29]. Denmark had well established technological practice regarding the digestion of manure and organic waste, 20 centralised and over 35 farmscale plants have been installed up till 1998. But no new centralised plants have been established since 1998 while development of farmscale plants has also been slowed down [31,32]. However, policies for decentralised CHP and encouraging the farmers to cooperate in small communities are in process [31,32]. Nigeria, a country which is fossil fuels rich and an oil exporting nation developing country has launched Biogas Technology Programme too [33]. Although in Pakistan biogas development was initiated as early as in 1959 and various departments and agencies were engaged. Pakistan Rural Support Programs Network (RSPN) installed 5360 fixed dome biogas plants till 2014. Pakistan Council of Appropriate Technology (PCAT) Initiatives led to the installation of 1000 biogas plants. Directorate General, New and Renewable Energy Resources (DGNRER) also supported biogas installation. [34-36]. Different policies and policy instruments, as well as other factors, which influence a potential expansion of biogas systems have identified and evaluated in many countries such as Sweden [2]

However, there are some constraints that may hinder this realization. These include economic, technical and socio-cultural constraints. Overcoming these constraints can make biogas technology penetrate even more than already projected into the rural communities and poor urban households have been suggested [33]. A UNDP report on energy for sustainable development [2] indicates that in developing countries there is often a lack of clarity on the specific roles and responsibilities of various departments/institutions/ministries/agencies involved in disseminating energy services in the rural areas leading to functional overlaps and an increase in pressure on the already scarce resources. The controlled digestion of waste yields several benefits and also some drawbacks. The advantages and disadvantages associated with biogas production and use are given in the following sections. 


\subsection{Advantages and Disadvantages}

\subsubsection{Advantages}

- Technology cheaper and simpler - than other bio-fuels, and ideal for small scale application

- Renewable energy - production of methane for use as a fuel.

- Pollution Control - limiting the release of methane, a greenhouse gas directly into the atmosphere

- Small land area - most of the structure can be built underground

- Cost effective - can be built and repaired with locally available materials, low operating costs

- Combined treatment - animal, human and solid organic waste treated in the same digester together

- $\quad$ Long service life - over 20 years

- Waste management - household and organic solid waste disposed of usefully and in a healthy manner, an effective method to manage the bio-wastes

- Organic fertilizer - the slurry has a high nutrient content and are ideal fertilizer

- Prevent deforestation - reduce pressure on fuel wood and self-sufficiency in energy for rural community

\subsubsection{Disadvantages}

a At large industrial scale not very attractive economically (as compared to other biofuels)

b Substrates need to contain high amounts of organic matter for biogas production

c Incomplete pathogen removal, the digestate might require further treatment

d Limited gas production below $15^{\circ} \mathrm{C}$

e Requires seeding

\section{Conclusions}

Anaerobic digestion is a technology that has long been used for the production of biogas. The technology is simple and tested and finds ready use in domestic and farming applications. The technology can contribute substantially to the sustainable energy recovery from organic waste particularly agriculture and municipal. The amount of agricultural and municipal organic wastes currently available for energy production is very large. Apart from significant energy source, it is important for comprehensive utilisation of biomass, agricultural, animal husbandry, forestry and fishery residues, thus controlling the pollution and protecting the environment. Waste management particularly in developing countries like Pakistan is one of the most serious environmental problems. The biogas technology provides two important benefits: environmentally safe waste management as well as the generation of clean renewable energy. Coordinating the factors like waste management, organic fertilizer, the biogas production and use may further optimize the promotion and development of agricultural and animal husbandry in rural areas, as well as improve the living conditions of rural communities. It may be one of the important options, which might gradually reduce the fossil fuels use.

This review, fundamentals of the biogas technology would encourage the utilization of the potentials of available biomass resources.

\section{REFERENCES}

[1] Y.A. Alemayehu, Enhancement and Optimization Mechanisms of Biogas Production for Rural Household Energy in Developing Countries: A review, Int'l Journal of Renewable Energy Development, 4(3), 189-196, 2015.

[2] UNDP, World Energy Assessment: Energy and the Challenge of Sustainability, United Nations Development Program, New York 2000.

[3] IEA, Fossil fuel energy consumption (\% of total), International Energy Agency Statistics, 2014. Online available from : http://data.worldbank.org/indicator/EG.USE.COMM.FO.ZS, Accessed on 18 December 2016

[4] X. Luo, J. Wang M. Dooner, J Clarke, Overview of current development in electrical energy storage technologies and the application potential in power system operation, Applied Energy, 137 (1), 511-536, 2015.

[5] Sagar A.D., Kartha S; Bioenergy and sustainable development? Annual Review of Environment and Resources, 32 (1): 131-167, (2007).

[6] J.-F.K. Akinbami, I.O. Akinwumi, A.T. Salami, Implications of environmental degradation in Nigeria, Natural Resources Forum, 20 (4): 319-331, 1996.

[7] N.H. Afgan and M.G. Carvalho MG, Multiple-Criteria Assessment of New and Renewable Energy Power Plants, Energy, 27(8), 739-755, 2002.

[8] P. Chartier, Biomass for Energy and the Environment, Pergamon Press, 1997.

[9] Z. Z. Ismail and A. R. Talib, Recycled medical cotton industry waste as a source of biogas recovery Journal of Cleaner Production, Volume 112, Part 5, 20, 4413-4418, January 2016.

[10] I. A. Raja, R. S. Abro and M. G. Douggar: Biogas energy for rural community of Pakistan, The European Congress on Renewable Energy Implementation, Athens, Greece, 5-7 May , 1997.

[11] I. Malico, J. Carrajola, C. Pinto Gomes, J.C. Lima. Biomass residues for energy production and habitat preservation. Case study in a montado area in Southwestern Europe, Journal of Cleaner Production, 112(5), 3676-3683, 2016

[12] N. J. Themelis and P. A. Ulloa, Methane generation in landfills, Renewable Energy, 32, 2007, 1243-1257.

[13] I. Angelidaki, L. Ellegaard, B. K. Ahring, A mathematical model for dynamic simulation of anaerobic digestion of complex substrates: Focusing on ammonia inhibition, 
Biotechnology and Bioengineering,42(2), 159-166, 1993

[14] Z. Bagi, N. Acs, B. Bálint, L. Horváth, K. Dobó, K. R. Perei, G. Rákhely, K. L. Kovács. Biotechnological intensification of biogas production, Appl Microbiol Biotechnol. 76(2):473-82. 2007.

[15] S. A. Gebrezgabher, M. P. M. Meuwissen, M. Prins, AGJMO Lansink; Economic analysis of anaerobic digestion-a case of green power biogas plant in the Netherlands. NJAS—Wageningen Journal of Life Sciences; 57(2):109-15, 2010

[16] F. Monnet; An introduction to anaerobic digestion of organic wastes, Fnal Report, Remade Scotland, 2003.

[17] M. Khurshid; Controlling desertification using decentralized biogas technology development at household Level, Arid agriculture University Rawalpindi, May 2009.

[18] U. Werner, U. Stohr and N. Flees; Biogas Plant in Animal Husbandry, Deuches Zentrum Fur Entwicklungstechtochnologyien, 1989

[19] S Wazir, I.A. Raja, Simple design and installation of biogas plant in KPK Pakistan, ESdev-VI, COMSATS Institute of Information Technology, Abbottabad, Pakistan, 2016.

[20] W. Liu, H. Lund, B.V. Mathiesen, 2011, Potential of renewable energy systems in China, Applied Energy 88(2):518-525, 2011.

[21] N. Shah, The role of bio-energy utilisation in sustainable development, Int. J. of Global Energy Issues, 9 (4-6): 365-381, 1997

[22] A. Andreasen, Status and perspectives for an accelerated development of biogas. In: Proceedings for the Nordic and European bioenergy conference bioenergy, Aarhus 2001.

[23] R. Arthur, M.F. Baidoo, E. Antwi, Biogas as a potential renewable energy source: A Ghanian case study Renewable Energy, 36(5): 1510-1516, 2011

[24] U.K Mirza, N Ahmad, T Majeed, An overview of biomass energy utilization in Pakistan, Renewable and Sustainable Energy Review, 12(7): 1988-1996, 2008.

[25] H. Suzuki, T. Yashida, Current situation and concerns with woody biomass use in ASEAN Countries, Japan Agricultural Research Quarterly, 43 (1) (2009), pp. 37-43.

[26] T. Gumartini, Biomass Energy in the Asia-Pacific Region: Current Status, Trends and Future Setting, FAO Regional Office, Bangkok (2009)

[27] FAO, Livestock Sector in Brief, Cambodia, FAO, Rome (2005).

[28] E. Buysman, APJ Mol, Market-based biogas sector development in least developed countries - The case of $\mathrm{X}$ Cambodia, Energy Policy, 63(1): 44-51, 2013.

[29] WJ Nes Van, T.D; Nhete;. Biogas for a better life: an African initiative, Appropriate Technology; Burnham 34(4): 58-62, 2007.

[30] L. Srivastava, I.H. Rehman, Energy for sustainable development in India: Linkages and strategic direction, Energy Policy, 34(5): 643-654, 2006.

[31] R. Raven, K. H. Gregersen, Biogas plants in Denmark: successes and setbacks, Renewable and Sustainable Energy Reviews, 11(1): 116-132, 2007

[32] E. W. Geels, RPJM Raven, Socio-cognitive evolution and co-evolution in competing technical trajectories: Biogas development in Denmark 1970-2000, International Journal of Sustainable Development and World, 14(1): 63-77, 2007.

[33] JFK Akinbami, M. O. Ilori, T. O. Oyebisi, I. O. Akinwumi, O. Adeoti, Biogas energy use in Nigeria: current status, future prospects and policy implications, Renewable and Sustainable Energy Review, 5(1): 97-112, 2001

[34] M. G. Doggar, I A Raja, Biogas: An Energy Options for 1000 Acre Agriculture Farm, ESdev VI, Conference, COMSATS Institute of Information Technology, Abbottabad, Pakistan, 2016.

[35] PCRET Report on "Biogas Technology: Experiences of PCRET (2010)". Ministry of Science and Technology Islamabad. RSPN (Pakistan Rural Support Network) 2011 \& 2014

[36] PREGA, Promotion of Renewable Energy, Energy Efficiency and Greenhouse Gas Abatement-Pakistan Country Report. Asian Development Bank; April 2004 